\title{
5 ASSESSMENT AND IDENTIFICATION OF PAEDIATRIC PRIMARY SURVEY POSITIVE PATIENTS
}

M Woollard, F Jewkes

Emerg Med J 2004; 21:511-517. doi: 10.1136/emj.2004.016501

$\mathrm{U}$ nwell children present particular challenges to the prehospital practitioner. The anatomy of children is different to that of adults, and this can result in differences in the presentation and severity of a range of conditions. Paediatric physiology also differs from that of adults, and although this means children often compensate very well to significant clinical illness it also carries the risk that a severe problem will be overlooked or underestimated. When compensatory mechanisms fail in children, they often do so rapidly, catastrophically, and irreversibly. The index of suspicion of the prehospital practitioner must therefore be higher when assessing the unwell child, and the threshold for hospital admission will consequently be lower than for an adult patient with similar findings. The emphasis should be on detecting and treating the seriously ill child at an early stage to prevent deterioration rather than attempting to cope with a decompensated, critically ill patient.

The paediatric section of the ABC of Community Emergency Care series will be divided into two articles. The objectives of this first paper are outlined in box 1 .

\section{Box 1 Article objectives}

\section{Objectives}

- To describe the anatomical and physiological differences between children and adults

- To describe the range of normal behaviours in children of different ages

- To discuss approaches to assessing children to minimise the effects of distress

- To identify the findings associated with primary survey positive patients

- To differentiate between compensating and decompensating primary survey positive patients

- To discuss where treatment should be started in primary survey positive patients

- To identify consent issues in caring for children

- To discuss child protection issues

While this first article concentrates on identifying or ruling out potentially time critical problems, it should be remembered that many children have problems that are not immediately life threatening. Common illnesses effecting children will be covered in a second article.

\section{SIGNIFICANT ANATOMICAL AND PHYSIOLOGICAL DIFFERENCES BETWEEN} CHILDREN AND ADULTS

See end of article for authors' affiliations

Correspondence to: Mr M Woollard, The James Cook University Hospital, Department of Academic Emergency Medicine, Education Centre, Marton Road, Middlesbrough TS4 3BW, UK; Malcolm. woollard@ukgateway.net

\section{Airway}

In infants (aged 0 to 1 years) and children (aged 1 to 8 years) the head is proportionately larger and the neck shorter than in adults. This can lead to neck flexion in the recumbent child, precipitating airway obstruction. The trachea in infants is also more malleable, and this coupled with the large tongue can result in airway obstruction if the head is over-extended when attempting to open the airway by positioning, particularly in infants. Milk teeth may be loose, and the smaller size of the mouth increases the risk of dislodgment or tissue damage. Compressing the surface of the skin below the lower jaw in an attempt to open the airway can result in the tongue being displaced and worsening obstruction. Infants less than 6 months old are obligate nasal breathers. The epiglottis is horseshoe shaped and the larynx higher and more anterior, the tracheal rings are soft and not fully formed, and the cricoid cartilage is the narrowest part of the upper airway. All have implications for airway management and the consequences of related illnesses.

\section{Breathing}

The total surface area of the lungs and the number of small airways is limited in infants and children and small diameters throughout the respiratory system increase the risk of obstruction. 
Table 1 Vital signs in children

\begin{tabular}{llll}
\hline Age $(\mathbf{y})$ & Breaths per minute & Heart rate & Systolic BP \\
\hline$<1$ & $30-40$ & $110-160$ & $70-90$ \\
$1-5$ & $25-30$ & $95-140$ & $80-100$ \\
$5-12$ & $20-25$ & $80-120$ & $90-110$ \\
$>12$ & $15-20$ & $60-100$ & $100-120$ \\
\hline
\end{tabular}

Infants have ribs that lie more horizontally and they therefore rely predominantly on the diaphragm for breathing. They are more prone to muscle fatigue and consequently respiratory failure. Increased metabolic rate and oxygen consumption contribute to higher respiratory rates than in adults (table 1).

\section{Circulation}

Infants and children have a comparatively small stroke volume but a higher cardiac output than in adults, facilitated by higher heart rates (table 1). Stroke volume increases with age as heart rate falls, but until the age of 2 the ability of the paediatric patient to increase stroke volume is limited. Systemic vascular resistance is lower in infants and children, evidenced by lower systolic blood pressure (table 1). The circulating volume to body weight ratio of children is higher than adults at $80-100 \mathrm{ml} / \mathrm{kg}$ but the total circulating volume is low. Comparatively minimal fluid loss can therefore be significant.

\section{Other considerations}

The surface area of children and infants is high, and this results in rapid heat loss and coupled with immature temperature regulation systems in infants presents an increased risk of hypothermia. Glycogen stores in the liver are limited and hypoglycaemia can be present in any paediatric patient that has been too ill to feed or subjected to high metabolic demands because of illness.

\section{RANGE OF NORMAL BEHAVIOURS IN CHILDREN AND ASSESSMENT STRATEGIES \\ Infants}

Table 2 outlines the normal range of behaviours of infants.

When assessing an infant ask the caregiver to hold the child and get down to "baby level". Use the child's name,

Table 2 Range of normal behaviours in infants

\begin{tabular}{ll}
\hline Age (months) & Activity \\
\hline$<2$ & Predominantly sleeping or eating \\
& Unable to differentiate between \\
& strangers and carers/family \\
& Spends more time awake \\
& Starting to make eye contact \\
& May follow movement of toys/lights \\
& with eyes \\
& May turn head towards sounds \\
& Active extremity movements \\
& May recognise caregivers \\
& Sits unsupported \\
& Reaches for objects and puts them in \\
& mouth \\
& Starts to vocalise sounds \\
& Recognises caregivers and afraid of \\
& separation from them; afraid of \\
& strangers \\
\hline
\end{tabular}

speak softly, and avoid sudden movements. Start by observing the child, then undertake a physical examination, starting with the least upsetting steps. Adjust the order of the examination according to the child's behaviour-for example, listen to breath sounds and count respiratory rate when the child is calm and before doing anything that may be painful or distressing. Make sure your hands and any instruments are warm, and remove only one item of clothing at a time to maintain body warmth.

\section{Children}

Table 3 outlines the range of normal behaviours for children aged $1-12$.

Observe the child from a distance initially and approach slowly, avoiding physical contact until the child is familiar with you. Allow children to stay with caregivers, and to sit on their lap if they wish to do so. Young children respond to praise-admire clothes or a favourite toy and recognise good behaviour. They may be soothed by being allowed to play with their own toys or by being allowed to hold instruments such as a stethoscope. Ask the caregiver to assist with the assessment, by removing clothes or holding an oxygen mask. Use very simple words and toys to demonstrate what you are going to do. Perform critical parts of the assessment whenever the child is at their most calm: consider examining from toes to head. Allow a limited element of control, asking which part the child would like you to examine first. Do not lie to children and, in particular, never tell them something will not hurt if it will!

School age children should be addressed directly. Using simple terms, explain what you are going to do, what you

Table 3 Range of normal behaviours in children aged 1 to 12 years

\begin{tabular}{ll}
\hline Age (y) & Activity \\
\hline $1-2$ & Initially crawling and walking supported by furniture, then \\
& walking and running \\
& Feeds themself \\
& Plays with toys \\
& Starting to communicate with increasing vocabulary; will \\
& understand more than they can yet say themselves \\
& Independent and opinionated: cannot be reasoned with \\
& Curious but with no sense of danger \\
& Frightened of strangers \\
& Illogical thinkers (by adult standards) \\
& May misinterpret what is said to them \\
& Fearful of being left alone, loss of control and being unwell \\
& Limited attention span \\
& Talkative \\
& Understand the relation between cause and effect \\
& Pleased to learn new skills \\
& Older children may understand simple explanations about \\
& how their bodies work and their illness \\
& Fearful about separation from parents, loss of control, \\
& pain, and disability \\
May be unable to express their thoughts & Desire to "fit in" with peers
\end{tabular}


think is wrong, and what will happen as a result of this, but limit the amount of information given. Explain interventions immediately before undertaking them but do not negotiate about whether or not to perform necessary procedures. Offer praise for cooperation. Children are modest and you should consider this by limiting the removal of clothing and the presence of non-caregivers.

\section{Adolescents}

Adolescents may indulge in risk taking behaviours and have a strong desire to "fit-in" with their peers. They may start to depend more on their friends for social support than their parents and will begin to exert their independence. They will be particularly modest about their bodies and how others see them, and will fear disfigurement. Mood swings are common and although it may be possible to rationalise with teenagers illness can result in a return to more immature developmental levels of behaviour.

When assessing adolescents, seek their permission to do so rather than the caregivers and explain what you are doing and why. Encourage questions and respect privacy and confidentiality, and be non-judgemental. If necessary, seek the support of the teenager's friends in persuading them to accept treatment.

\section{Children with special learning needs}

Children with special learning needs may normally have a behavioural range that is equivalent to a child younger than their true age in years. Parents or carers will be able to advise what is normal for the child, and you should use the approach appropriate for the child's mental rather than actual age. However, it is important to remember that children with a physical disability will often have a normal mental age for their years and they should be communicated with accordingly.

\section{PRIMARY SURVEY POSITIVE PATIENTS}

Paediatric primary survey positive patients fall into one of two groups. Those who are seriously ill but are currently compensating require immediate transportation to definitive care to prevent further deterioration. Prehospital treatment for this group of patients should be given on route: treatment that cannot be practically administered by a single practitioner in the back of a moving ambulance should be postponed until arrival at hospital, unless the patient decompensates before arrival. Those that are seriously ill but are no longer able to compensate will require some lifesaving intervention "on-scene" before transportation to hospital but this should be strictly limited to that which will allow delivery of a live child to the emergency department.

\section{Pitfall}

Cessation of wheeze in a child with severe asthma may be mis-interpreted as an improvement in the patient's condition

\section{俞 Tip}

Measure capillary refill time centrally, on the forehead or sternum
Box 2 Main features of paediatric primary survey

Airway

- Is the airway noisy (snoring, stridor, wheeze, grunting, muffled or hoarse speech)?

Work of breathing

- Will the child lie flat? Are they in the tripod or "sniffing" position?

- Are accessory muscles being used (head bobbing in infants)? Or is there minimal movement of the chest wall?

- Is there sternal, supra-clavicular, sub-sternal, or intercostal recession present? (see fig 1)

- Is nasal flaring present?

- Is the respiratory rate fast, slow, or normal?

- Is cyanosis present?

- Is there a very recent history of wheezing that has now stopped?

- Is air movement audible on auscultation?

-What is the $\mathrm{SpO}_{2}$ ?

\section{Circulation}

- Is skin colour normal, or is it pale or mottled?

- Is there an increased respiratory rate without increased work of breathing?

-What is the temperature of the skin? Is it cool peripherally but warm centrally?

- Is the pulse rate fast, slow, or normal?

- Is the pulse volume weak or strong?

- Is the capillary refill time normal or prolonged?

Disability

- What is the AVPU score? (Alert, response to Verbal stimuli, response to Pain, Unresponsive)

- Is the child mobile? Do they run away? Or is there limited movement with poor muscle tone?

- Do they interact with carers or toys or are they disinterested or unresponsive?

- If they are crying or speaking, is this strong or weak?

- If crying, can they be consoled?

- Do they fix their gaze on responders or carers, or do they have a "glazed" appearance?

- Is the child's behaviour normal for their developmental age?

- Is the child fitting?

- Is the child stiff or floppy?

\section{Exposure}

- Is there evidence of fever?

- Is there a non-blanching rash present?

What is the blood glucose level?

\section{球 Tip}

Remember: $A B C D E F G=A B C$ s plus Don't Ever Forget the Glucose

\section{Pitfall}

Peripheral cyanosis is normal in babies up to about 3 months 


\section{Recognition}

Box 2 describes the main features of the primary survey for children.

\section{Decompensating primary survey positive patients}

Table 4 describes the significant findings and pre-transportation treatment for children who are primary survey positive and decompensating. Parents should be encouraged to hold small children who remain alert to minimise distress.

Once lifesaving interventions have been initiated, move the child to the ambulance and transport immediately, continuing treatment on route as described in table 5.

\section{Compensating primary survey positive patients}

Seriously ill but compensating children will have signs of either shock or respiratory distress but will have a comparatively normal appearance and level of consciousness. Transportation to hospital should be commenced immediately for such patients and whatever appropriate treatment from table 4 that is practical to provide in a moving ambulance provided on route. Parents should be encouraged to hold small children to minimise distress.

Table 5 describes the findings associated with compensating primary survey positive patients and on route treatment.

\section{悀 Tip}

Remember to pre-alert the receiving hospital of your estimated time of arrival and the child's age and condition

\section{璯 Pitfall}

In cases of suspected epiglottitis or severe croup in a spontaneously breathing child withhold all interventions. Never attempt to examine the airway, to use airway adjuncts, to remove the child from their carer, or to do anything that may increase distress

\section{谕 Tip}

In cases of suspected epiglottitis or severe croup with respiratory arrest initially attempt ventilation with a pocket mask with oxygen or bag-valve-mask. If this is impossible and laryngoscopy and intubation are required but the glottis is obscured by swollen tissue, ask an assistant to press down on the chest and hold it in compression. If a bubble appears, attempt to pass an endotracheal tube through it. If this fails, perform needle cricothyroidotomy.

\section{媮 Tip}

Patients with a changed level of consciousness or with limited interaction with carers in the presence or absence of abnormal respiratory or circulatory signs should be considered to be decompensating

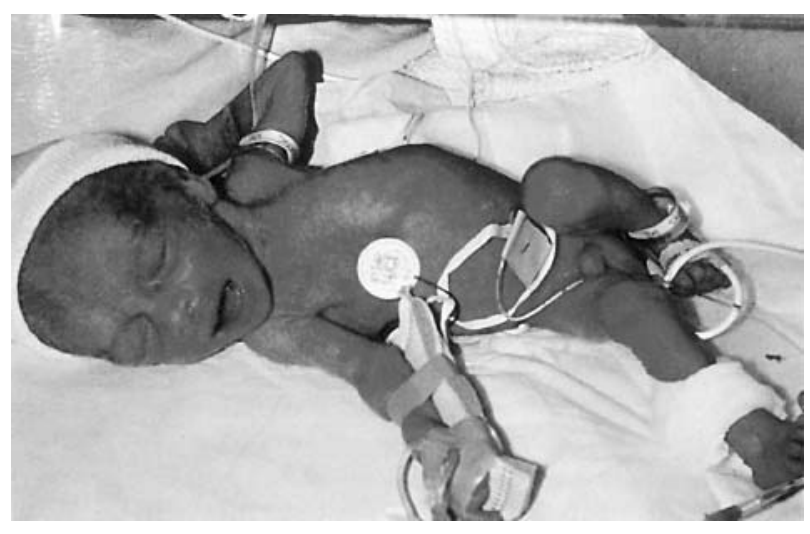

Figure 1 Infant with sternal recession.

\section{PRIMARY SURVEY NEGATIVE PATIENTS WITH NEED FOR EARLY HOSPITAL ATTENDANCE}

Primary survey negative patients with the findings listed in box 3 will require hospital admission.

Parents may have requested the assistance of healthcare providers after using the baby check scoring system. ${ }^{1}$ This uses a simple 19 point check list to help parents assess the severity of illness in babies up to 6 months old, and to determine the need for medical assessment.

Box 3 Diagnostic criteria for primary survey negative patients requiring hospital admission

Findings suggesting need for early hospital admission in primary survey negative patients

- Noisy upper airway in the absence of respiratory distress or changed mentation

- Suspected foreign body inhalation

- History of apnoeic episode (child well on arrival of prehospital practitioner)

- Asthma refractory to bronchodilators

- Inability to feed

- Non-blanching rash in an otherwise well child

- First fit of any cause, including febrile convulsions

- Unexpected increase in number of fits in a child prone to convulsions

- More than one fit in a 24 hour period in a febrile child

- Fever $>38.5^{\circ} \mathrm{C}$ in a child under 6 months

\section{Box 4 Parental responsibility}

Parental responsibility is given to the following adults by the Childrens Act 1989:

- Both parents if married at any time since the child's conception;

- The mother alone if the child is illegitimate, unless the father has obtained agreement of the mother or a court order;

- A local authority if the child is in care or under a care order;

- An appointed guardian;

- Those with a residence order;

- Adoptive parents;

- Those with an emergency protection order (usually a local authority) 
Table 4 Recognition and pre-transportation treatment of the decompensating primary survey positive patient

\begin{tabular}{|c|c|c|}
\hline \multirow{2}{*}{$\begin{array}{l}\text { Problem } \\
\text { Respiratory } \\
\text { failure }\end{array}$} & Findings & Pre-transportation treatment \\
\hline & $\begin{array}{l}\text { Noisy upper airway becoming quiet } \\
\text { without improvement in condition }\end{array}$ & $\begin{array}{l}\text { Secure airway using simple manoeuvres if } \\
\text { possible: use advanced interventions } \\
\text { (for example, intubation) only if } \\
\text { simple manoeuvres fail }\end{array}$ \\
\hline & $\begin{array}{l}\text { Very rapid and shallow or slow weak } \\
\text { respirations }\end{array}$ & $\begin{array}{l}\text { Give high concentration oxygen via } \\
\text { non-rebreathing mask }\end{array}$ \\
\hline & $\begin{array}{l}\text { Decreasing evidence of increased } \\
\text { work of breathing because of exhaustion }\end{array}$ & $\begin{array}{l}\text { Consider assisting ventilation with bag } \\
\text { valve mask if respiratory rate is very } \\
\text { fast or slow }\end{array}$ \\
\hline & $\begin{array}{l}\text { Significantly decreased air entry on } \\
\text { auscultation }\end{array}$ & $\begin{array}{l}\text { Consider nebulised adrenaline in } \\
\text { the presence of suspected croup } \\
(5 \mathrm{ml} \text { of } 1: 1000 \text { once only) }\end{array}$ \\
\hline & - Limited chest expansion & $\begin{array}{l}\text { In the presence of wheeze consider } \\
\text { nebulisation with } \beta_{2} \text { agonist and } \\
\text { anticholinergic (for example, salbutamol } \\
\text { and ipratropium) }\end{array}$ \\
\hline & $\begin{array}{l}\text { Loss of wheeze without improvement in } \\
\text { condition }\end{array}$ & - Decompress tension pneumothorax \\
\hline & $\begin{array}{l}\text { } \mathrm{SpO}_{2} \text { less than } 90 \% \text { on high } \\
\text { concentration oxygen }\end{array}$ & $\begin{array}{l}\text { Consider intravenous/intraosseous } \\
10 \% \text { dextrose } 5 \mathrm{ml} / \mathrm{kg}\end{array}$ \\
\hline & - Cyanosis & \\
\hline & - Reduced AVPU score & \\
\hline & - Flaccid or increased muscle tone & \\
\hline & - No interaction with carers or responders & \\
\hline & - Glazed, unfocused gaze & \\
\hline & - Abnormal, weak, or absent cry & \\
\hline \multirow[t]{11}{*}{$\begin{array}{l}\text { Circulatory } \\
\text { failure }\end{array}$} & $\begin{array}{l}\text { Hypoglycaemia } \\
\text { Increased respiratory rate in the absence of } \\
\text { increased work of breathing }\end{array}$ & $\begin{array}{l}\text { Secure airway using simple manoeuvres } \\
\text { if possible: use advanced interventions } \\
\text { (for example, intubation) only if simple } \\
\text { manoeuvres fail }\end{array}$ \\
\hline & - Central pallor, mottling, or cyanosis & $\begin{array}{l}\text { Give high concentration oxygen via non- } \\
\text { rebreathing mask }\end{array}$ \\
\hline & Cool skin centrally & $\begin{array}{l}\text { Consider intravenous/intraosseous fluid } \\
\text { challenge of } 20 \mathrm{ml} / \mathrm{kg}\end{array}$ \\
\hline & $\begin{array}{l}\text { Bradycardia or falling heart rate } \\
\text { in the absence of } \\
\text { improvement in condition }\end{array}$ & $\begin{array}{l}\text { Consider intravenous/intraosseous } 10 \% \\
\text { dextrose } 5 \mathrm{ml} / \mathrm{kg}\end{array}$ \\
\hline & $\begin{array}{l}\text { Central capillary refill time }>5 \text { seconds } \\
\text { or absent }\end{array}$ & - Consider benzylpenicillin 300 mg $/ \mathrm{kg} \mathrm{IV}$ \\
\hline & - Reduced AVPU score & \\
\hline & - Flaccid muscle tone & \\
\hline & - No interaction with carers or responders & \\
\hline & - Glazed, unfocused gaze & \\
\hline & - Weak or absent cry & \\
\hline & $\begin{array}{l}\text { - Non-blanching rash and history of flu-lik } \\
\text { illness }\end{array}$ & \\
\hline \multirow[t]{7}{*}{$\begin{array}{l}\text { Central nervous } \\
\text { system failure }\end{array}$} & - Reduced AVPU score & $\begin{array}{l}\text { Consider the presence of undiagnosed } \\
\text { respiratory or circulatory failure and treat } \\
\text { accordingly. Otherwise: }\end{array}$ \\
\hline & - Flaccid muscle tone & $\begin{array}{l}\text { Secure airway using simple manoeuvres } \\
\text { if possible: use advanced interventions } \\
\text { (for example, intubation) only if simple } \\
\text { manoeuvres fail }\end{array}$ \\
\hline & - No interaction with carers or responders & $\begin{array}{l}\text { Give high concentration oxygen via } \\
\text { non-rebreathing mask }\end{array}$ \\
\hline & - Glazed, unfocused gaze & $\begin{array}{l}\text { Consider assisting ventilation with } \\
\text { bag valve mask if respiratory rate is very } \\
\text { fast or slow }\end{array}$ \\
\hline & - Weak or absent cry & $\begin{array}{l}\text { Consider rectal diazepam }(0 \text { to } 1 \mathrm{yr} \\
2.5 \mathrm{mg}, 1 \text { to } 3 \text { years } 5 \mathrm{mg}, 4 \text { to } 12 \text { years } \\
10 \mathrm{mg} \text { ) or IV diazepam } 250 \text { to } \\
400 \mu \mathrm{kg} / \mathrm{kg}\end{array}$ \\
\hline & $\begin{array}{l}\text { Continuous fits, or failure to regain } \\
\text { consciousness between fits }\end{array}$ & $\begin{array}{l}\text { Consider intravenous/intraosseous } 10 \% \\
\text { glucose }(5 \mathrm{ml} / \mathrm{kg})\end{array}$ \\
\hline & - Hypoglycaemia & \\
\hline
\end{tabular}


Table 5 Findings associated with compensating primary survey positive patients and on route treatment

\begin{tabular}{|c|c|c|}
\hline Problem & Findings & Treatment on route to hospital \\
\hline \multirow[t]{16}{*}{$\begin{array}{l}\text { Respiratory } \\
\text { distress }\end{array}$} & $\begin{array}{l}\text { Noisy upper airway (snoring, stridor, } \\
\text { muffled, or hoarse speech) }\end{array}$ & $\begin{array}{l}\text { Secure airway using simple } \\
\text { manoeuvres if required: use advanced } \\
\text { interventions (for example, intubation) } \\
\text { only if simple manoeuvres fail }\end{array}$ \\
\hline & Grunting & $\begin{array}{l}\text { Give high concentration oxygen via } \\
\text { non-rebreathing mask }\end{array}$ \\
\hline & - Increased respiratory rate & $\begin{array}{l}\text { Consider nebulised budesonide in the } \\
\text { presence of suspected croup ( } 2 \mathrm{mg} \\
\text { once only) or oral corticosteroids } \\
\text { (dexamethasone syrup } 0.15 \mathrm{mg} / \mathrm{kg} \text { ) }\end{array}$ \\
\hline & $\begin{array}{l}\text { Refuses to lie flat, or adopts tripod or } \\
\text { sniffing position }\end{array}$ & $\begin{array}{l}\text { In the presence of wheeze consider } \\
\text { nebulisation with } \beta_{2} \text { agonist and } \\
\text { anticholinergic (for example, } \\
\text { salbutamol and ipratropium) }\end{array}$ \\
\hline & $\begin{array}{l}\text { Use of accessory muscles (head bobbing } \\
\text { in infants) }\end{array}$ & \\
\hline & $\begin{array}{l}\text { Sternal, sub-sternal, supra-clavicular, or } \\
\text { intercostal recession present }\end{array}$ & \\
\hline & - Nasal flaring & \\
\hline & - Increased or asymmetrical chest expansion & \\
\hline & Wheezing & \\
\hline & - $\mathrm{SpO}_{2}$ less than $94 \%$ on room air & \\
\hline & - Pallor or peripheral cyanosis & \\
\hline & - Normal AVPU score & \\
\hline & Good muscle tone; may be playing with toys & \\
\hline & - Interacts with carers or responders & \\
\hline & Focused gaze & \\
\hline & Strong cry & \\
\hline \multirow[t]{9}{*}{$\begin{array}{l}\text { Compensated } \\
\text { shock }\end{array}$} & $\begin{array}{l}\text { Increased respiratory rate in the absence } \\
\text { of increased work of breathing }\end{array}$ & $\begin{array}{l}\text { Secure airway using simple man- } \\
\text { oeuvres if appropriate: use advanced } \\
\text { interventions (for example, intubation) } \\
\text { only if simple manoeuvres fail }\end{array}$ \\
\hline & - Peripheral pallor, mottling, or cyanosis & $\begin{array}{l}\text { Give high concentration oxygen via } \\
\text { non-rebreathing mask }\end{array}$ \\
\hline & Cool skin peripherally, warm centrally & $\begin{array}{l}\text { Consider intravenous/intraosseous fluid } \\
\text { challenge of } 20 \mathrm{ml} / \mathrm{kg}\end{array}$ \\
\hline & Increased heart rate & \\
\hline & - Normal AVPU score & \\
\hline & Good muscle tone; may be playing with toys & \\
\hline & Interacts with carers or responders & \\
\hline & $\rightarrow$ Focused gaze & \\
\hline & - Strong cry & \\
\hline
\end{tabular}

\section{CONSENT TO TREATMENT}

Children (that is, patients under the age of 18) can be classified into three groups with respect to legal considerations regarding consent for treatment, or its refusal.

The doctrine of necessity may be applied if lifesaving treatment is required for paediatric patients in any of these groups and consent cannot be obtained in a timely manner in the required way.

\section{Minor over the age of 16}

Children over the age of 16 should normally be treated as competent adults. Informed consent to treatment should be sought from the child. Adults with parental responsibility may not refuse treatment on behalf of the minor if the child has consented to it. Adults with parental responsibility may, however, override the decision of a minor to refuse lifesaving treatment, as may a court of law. If both a child and those with parental responsibility refuse lifesaving treatment this can be over-ridden by a court of law or, in an emergency, health professionals. "Parental responsibility" is defined in box 4 .
In the event that a child over the age of 16 is of unsound mind, consent may be obtained from those with responsibility or, if this is not immediately available, the doctrine of necessity can be applied.

\section{Minor under the age of 16 who is "Gillick aware"}

"Gillick awareness" is defined as the child having achieved sufficient understanding and intelligence to fully understand the treatment that is being suggested. The principles described for minors over the age of 16 should be applied to children under 16 who are "Gillick aware". The law assumes that a child under the age of 16 refusing lifesaving treatment is unlikely to be Gillick aware and is not, therefore, competent to decline treatment.

\section{Minor under the age of 16 who is not "Gillick aware"} If possible, obtain informed consent to treatment from an adult with parental responsibility (see box 4). If such an adult is not immediately available and treatment cannot be delayed, the legal doctrine of necessity may be invoked if the treatment is necessary to save life, ensure improvement, or 
prevent deterioration in health. The doctrine of necessity can only apply if the treatment provided is in accordance with normal current medical practice and is restricted to that required until parental consent can be obtained.

If those with parental responsibility refuse treatment, a court order should be sought. If this is not feasible because treatment is life saving and cannot be delayed, the practitioner should discuss the need for the treatment in detail and record this in the presence of a witness. If possible, a colleague should provide a supporting written recommendation that the treatment is necessary and appropriate, and a defence union contacted.

\section{CHILD PROTECTION}

Healthcare providers have a duty of care to be alert to the signs of possible child abuse. This may occur in the form of neglect, physical injury, or sexual or emotional abuse, and may be perpetrated by other children as well as adults.

\section{Identifying potential abuse}

A range of pointers to child abuse may be present. Parents or carers may show limited concern for an injured child, or behave aggressively or defensively towards health professionals without provocation. They may refuse to allow the child to be hospitalised or referred for further care, decline to travel with the child to hospital, or refuse to leave the child alone with health practitioners. There may have been a delay in calling for help, or the story of how an injury occurred may be vague or vary when repeated or described by another person, or the account may not fit the injury pattern.

The child may tell health professionals that they have been abused, but more often their abnormal pattern of behaviour will suggest the problem. The child may not seek comfort from their parent or carer, and may be unusually willing to go to a previously unknown health worker. They may appear withdrawn or frightened- "frozen watchfulness" may indicate repetitive abuse.

Physical signs of abuse can include multiple injuries with different stages of healing, such as bruises of different colouration or fractures of different ages. Long bone or rib fractures in young children with limited mobility may suggest the suspicion of violence, as can spinal and head injuries. Soft tissue injuries associated with abuse include cigarette burns or immersion scalds of hands or feet, and imprints of hands, belts or other objects and human bite marks.

Sexual abuse should be considered in the presence of sexual knowledge unusual for the age of the child, unexplained pregnancy, sexually transmitted disease, or injuries to the perineum or sexual organs.

\section{Taking action}

All healthcare professionals should be familiar with their organisation's procedures for child welfare and protection. In the event that child abuse is suspected it is not the role of healthcare workers to undertake an investigation. In particular, children should not be asked leading questions as this may prejudice any criminal inquiry. Concerns should be referred to social services without delay or, in the event that immediate action is required, to the police. Child welfare policies should document how to make contact with the appropriate organisations outside of normal working hours. Verbal notifications must be followed up with a written report within 48 hours, and all findings and concerns should be documented in the patient record. Ensure that a referral not requiring immediate action is acknowledged in writing: if it is not, follow this up with the relevant agency.

If a child reports abuse communicate with them in a language appropriate to their age. Do not, however, promise that you will not disclose the information to the appropriate agencies.

In the event that there are concerns that a child is at immediate risk of further harm, attempt to persuade parents or carers that hospital admission is appropriate. Practitioners should never behave in a judgemental manner towards parents or reveal their suspicions to them, however.

\section{Further reading}

Advanced Life Support Group, eds. Advanced paediatric life support. The practical approach. 3rd edn. Manchester: Advanced Life Support Group, 2001.

Advanced Life Support Group, eds. Pre-hospital paediatric life support. Manchester: Advanced Life Support Group, 1999.

American Academy of Pediatrics. Pediatric education for prehospital professionals. Sudbury, MA, USA: Jones and Bartlett, 2000.

Department of Health. What to do if you are worried a child is being abused (summary). London: Crown Publishing, 2003.

Montague A. Legal problems in emergency medicine. Oxford: Oxford University Press, 1996.

Morley CJ, Thornton AJ, Cole TJ, et al. Baby check. http:// nicutools.orcon.net.nz/MediCalcs/BabyCheck.html (accessed 29 Feb 2004).

\section{ACKNOWLEDGEMENTS}

Thanks to Jim Wardrope, Peter Driscoll, and Colville Laird whose feedback resulted in improvements to earlier drafts of this paper.

\section{AUTHOR CONTRIBUTIONS}

Malcolm Woollard wrote the first draft of the paper. Malcolm Woollard and Fiona Jewkes edited all subsequent drafts.

[...............

Authors' affiliations

M Woollard, Pre-hospital Care Research Unit, Department of Academic Emergency Medicine, The James Cook University Hospital/University of Teesside, Middlesbrough, UK

F Jewkes, Wiltshire Ambulance Service NHS Trust, UK

\section{REFERENCE}

1 Morley CJ, Thornton AJ, Cole TJ, et al. A scoring system to grade the severity of acute systemic illness in babies under 6 months old. Arch Dis Child 1991;66:100-5. 